\title{
Overexpression of Activin Receptor-like Kinase 7 in Breast Cancer Cells Is Associated with Decreased Cell Growth and Adhesion
}

\author{
TINGTING HU ${ }^{1,2}$, FENGXI SU $^{2}$, WENGUO JIANG ${ }^{1}$ and D. ALWYN DART ${ }^{1}$ \\ ${ }^{1}$ Cardiff China Medical Research Collaborative, Cardiff University School of Medicine, \\ Henry Wellcome Building, Heath Park, Cardiff, U.K.; \\ ${ }^{2}$ Breast Tumor Center, Sun Yat-Sen Memorial Hospital, Sun Yat-Sen University, Guangzhou, P.R. China
}

\begin{abstract}
Aim: To examine the expression and function of activin receptor-like kinase 7 (ALK7) in breast cancer, its association with disease prognosis, and its impact on breast cancer cell function. Patients and Methods: A cohort of patients with breast cancer were examined for ALK7 expression in association with pathological and clinical aspects. In vitro cell assays of ALK7 were investigated using an expression plasmid. Results: Overall higher levels of ALK7 transcripts were seen in the breast cancer samples vs. normal tissue. However, within the cancer cohort, lower levels of ALK7 transcript were associated with poor prognosis. Patients with lower expression of ALK7 also had shorter survival. Overexpression of ALK7 reduced proliferation and adhesion of breast cancer cells in vitro. We found that overexpressed ALK7 had complex effects on the MCF-7 cell sensitivity to chemotherapy drugs. Conclusion: Decreased expression of ALK7 in breast cancer is correlated with poor prognosis. ALK 7 is a negative regulator of adhesion and proliferation of breast cancer cells. This suggests that ALK7 is a potential tumor suppressor in breast cancer.
\end{abstract}

Breast cancer is currently the leading cause of cancerassociated death for women, and is the most frequent female malignancy worldwide. In the United States, breast cancer alone is expected to account for $29 \%$ of all new cancer diagnoses and $14 \%$ of total cancer deaths in women (1). This represents an urgent public health problem, therefore, it is vital to explore the molecular mechanisms underlying breast cancer development and progression.

This article is freely accessible online.

Correspondence to: Fengxi Su, Breast Tumor Center, Sun Yat-Sen Memorial Hospital, Sun Yat-Sen University, Guangzhou, 510288, People's Republic of China. E-mail: fengxisu@vip.163.com

Key Words: Breast cancer, ALK7, TGFb, MCF7, MDA-MB-231.
The transforming growth factor- $\beta$ (TGF- $\beta$ ) superfamily has been shown to regulate a variety of cellular processes such as cell proliferation, differentiation, apoptosis, adhesion, and migration, and play key roles in development and carcinogenesis. The TGF- $\beta$ superfamily encompasses more than 35 members of structurally-related growth factors including TGF- $\beta$ s, activins, bone morphogenetic proteins (BMPs), differentiation factors and other factors such as nodal and its related proteins (1-3). TGF- $\beta$ has been implicated as playing paradoxical roles in breast carcinogenesis, with both tumour-suppressing and prooncogenic activities (4). The TGF- $\beta$ superfamily transmits their signals from the cell surface via transmembrane serine/threonine kinase receptor complexes, consisting of type I and type II receptors. In mammals, five type II receptors and seven type I receptors (referred to as activin receptor-like kinase, ALK 1-7) have been identified (3, 5-7). Upon ligand binding, the type II receptors recruit and transphosphorylate type I receptors. The latter, in turn, phosphorylate the receptor-activated SMAD (small family member, identified in Caenorhabditis elegans and mothers against decapentaplegic homolog) proteins (R-SMADs). Activated R-SMADs then form a protein complex with SMAD4 and are translocated into the nucleus where they interact with additional transcription factors and co-activators or co-repressors to regulate target gene expression (1-3).

ALK7 was first discovered in the rat as an orphan receptor (8) and was later reported to be able to mediate signals of nodal, activin $\mathrm{B}$, and activin $\mathrm{AB}(9,10)$. Functionally, activation of ALK7 has been shown to suppress cell proliferation in the rat neuronal cell line PC12 (11). In addition, constitutively activated ALK7 induces apoptosis of hepatoma and pancreatic $\beta$ cells $(12,13)$. Nodal acts via ALK7 to inhibit proliferation and induce apoptosis of human trophoblast cells (14), and epithelial ovarian cancer cells $(15,16)$. These findings support the role of nodal-ALK7 pathway in mediating cell proliferation 
and apoptosis of cancer cells. Immunohistochemical analysis has shown that ALK7 is more frequently and much more intensely expressed in adjacent normal tissues, adenosis, and fibroadenoma tissues than in malignant tissues (17). In addition, the nodal-ALK7 signalling pathway has been found to exert antiproliferative and proapoptotic effects on breast cancer cells (18).

In order to explore the role of ALK7 in breast cancer, the present study aimed to examine the expression of ALK7 in a cohort of human breast cancer samples and its association with disease prognosis. We also investigated the impact of this molecule on the function of breast cancer cells in vitro.

\section{Materials and Methods}

In silico analysis. Analysis of clinical data of breast cancer cases was carried out using the manually curated Kmplot website (http://kmplot.com/analysis/). All the gene-expression, relapse-free and overall survival data were downloaded from GEO (Affymetrix microarrays only), EGA and TCGA websites. A PostgreSQL server was used to integrated gene expression and clinical data. The median expression was used as the cut-off value which divided the patients into two groups (high or low expression). The KaplanMeier survival model was used to analyse the overall survival and log-rank method to compare overall survival between two groups. We utilsed two data sets for ALK7 expression in breast cancer, each having 1660 patients.

Cell lines and cell culture. Human breast cancer cell lines MDAMB-231, MCF-7, ZR-75-1, BT-20. BT-549, MDA-MB-436, BT-483 and SK-BR-3 were obtained from the European Collection of Animal Cell Cultures (Salisbury, UK). Cells were routinely cultured with Dulbecco's modified Eagle's medium (DMEM) containing $10 \%$ foetal bovine serum, $100 \mathrm{U} / \mathrm{ml}$ penicillin, $0.1 \mathrm{mg} / \mathrm{ml}$ streptomycin and $0.25 \mu \mathrm{g} / \mathrm{ml}$ amphotericin B at $37^{\circ} \mathrm{C}$ with $5 \% \mathrm{CO}_{2}$. BT-483 cells were maintained in RPMI and SK-Br-3 were maintained in McCoy's 5A medium.

For the hormone-starvation experiments, cells were cultured for $72 \mathrm{~h}$ in phenol red-free medium supplemented with $5 \%$ charcoalstripped foetal bovine serum, $100 \mathrm{U} / \mathrm{ml}$ penicillin, $0.1 \mathrm{mg} / \mathrm{ml}$ streptomycin and $0.25 \mu \mathrm{g} / \mathrm{ml}$ amphotericin B (starvation medium). Cells were then treated with oestradiol $(0-100 \mathrm{nM}$, final concentration) and incubated for $24 \mathrm{~h}$.

Human breast specimens. A total of 111 breast samples were collected immediately after surgery and stored at $-80^{\circ} \mathrm{C}$ until use, with approval of the BroTaf Health Authority local Ethics Committee (Wales, U.K.) - approval numbers 01/4303 (19/12/2001) and 01/4046 (06/08/2001). It included 91 breast cancer tissues and 20 normal breast tissues. A consultant pathologist verified all the specimens used in the current study (Table I).

RNA extraction and reverse transcription. Total RNA extraction from frozen tissues and cultured cells was performed using Tri Reagent (Sigma-Aldrich, Inc, St Louis' MO, USA) following the manufacturer's protocols. RNA was quantified using a Nanodrop spectrophotometer. RNA $(0.5 \mu \mathrm{g})$ was reverse-transcribed using iScript ${ }^{\mathrm{TM}}$ cDNA Synthesis Kit (Bio-Rad Laboratories, Hercules, CA, USA).
Table I. Transcript levels of activin receptor-like kinase 7 (ALK7) in breast cancer. (Samples collected from the BroTaf Health Authority Wales, UK).

\begin{tabular}{|c|c|c|c|}
\hline $\begin{array}{l}\text { Clinical/pathological } \\
\text { feature }\end{array}$ & $\begin{array}{l}\text { Samples, } \\
\mathrm{n}\end{array}$ & $\begin{array}{l}\text { ALK7 Copy no., } \\
\text { mean } \pm \text { SD }\end{array}$ & $p$-Value \\
\hline \multicolumn{4}{|l|}{ Tissue sample } \\
\hline Normal & 20 & $5,591 \pm 12,037$ & \\
\hline Tumor & 91 & $38,370 \pm 342,921$ & 0.015 \\
\hline \multicolumn{4}{|l|}{ Grade } \\
\hline 1 & 11 & $194 \pm 507$ & \\
\hline 2 & 31 & $107,009 \pm 587,440$ & 0.597 \\
\hline 3 & 48 & $3,578 \pm 14,072$ & 0.206 \\
\hline \multicolumn{4}{|l|}{ NPI } \\
\hline $1(<3.5)$ & 44 & $75,819 \pm 493,086$ & \\
\hline $2(3.5-5.4)$ & 30 & $5,143 \pm 17,619$ & 1.000 \\
\hline $3(>5.4)$ & 13 & $69 \pm 142.8$ & 0.518 \\
\hline \multicolumn{4}{|l|}{ TNM } \\
\hline 1 & 47 & $70,696 \pm 477,144$ & \\
\hline 2 & 31 & $2,659 \pm 11,001$ & 0.091 \\
\hline 3 & 5 & $141.2 \pm 173.2$ & 0.545 \\
\hline 4 & 4 & $39.8 \pm 36.2$ & 0.195 \\
\hline \multicolumn{4}{|l|}{ Clinical outcome } \\
\hline Disease-free & 63 & $2,205 \pm 9,142$ & \\
\hline \multicolumn{4}{|l|}{ Poor outcome } \\
\hline With metastasis & 5 & $15,510 \pm 15,497$ & 0.935 \\
\hline With local recurrence & 4 & $107.2 \pm 169.1$ & 0.570 \\
\hline Died of breast cancer & 14 & $233,767 \pm 874,464$ & 0.746 \\
\hline \multicolumn{4}{|l|}{ Histology } \\
\hline Ductal & 71 & $2,499 \pm 11,647$ & \\
\hline Lobular & 11 & $297,640 \pm 986,484$ & 0.422 \\
\hline Other & 5 & $136.1 \pm 184.0$ & 0.900 \\
\hline \multicolumn{4}{|l|}{ ER status } \\
\hline $\mathrm{ER} \alpha-$ & 57 & $59,967 \pm 433,194$ & \\
\hline $\mathrm{ER} \alpha+$ & 30 & $2,382 \pm 11,095$ & 0.904 \\
\hline $\mathrm{ER} \beta-$ & 69 & $49,929 \pm 393,773$ & \\
\hline$E R \beta+$ & 20 & $2,225 \pm 8,805$ & 0.673 \\
\hline
\end{tabular}

NPI: Nottingham Prognostic Index; TNM: tumour/lymph node/metastasis system; ER $\alpha / \beta$ : oestrogen receptor alpha/beta. Bold $p$ values are statistically significant.

Polymerase chain reaction (PCR) for ALK7. PCR was then carried out using a ReadyMix PCR Reaction Mix with $\mathrm{MgCl}_{2}$ (SigmaAldrich, Inc.) on a 2720 Thermo Cycler (Applied Biosystems, Warrington, UK). The sequences of $A L K 7$ primer used were: Forward (F): 5'-GACATGAAAACATCCTTGGT-3', and reverse (R): 5'ACTTCTGGTCACAAACAACC-3'. Reactions were carried out under the following conditions: $94^{\circ} \mathrm{C}$ for $5 \mathrm{~min}, 30$ cycles of $94^{\circ} \mathrm{C}$ for $30 \mathrm{~s}, 55^{\circ} \mathrm{C}$ for $30 \mathrm{~s}$ and $72^{\circ} \mathrm{C}$ for $30 \mathrm{~s}$, followed by a final extension of $7 \mathrm{~min}$ at $72^{\circ} \mathrm{C}$. PCR products were separated on a $1.5 \%$ agarose gel and photographed using a VisiDoc-It imaging system (Ultra-Violet Products Ltd, Upland, CA, USA) after staining with SYBR safe dye.

Real-time quantitative ( $q$ )PCR. Transcript levels were determined using real-time PCR based on Amplifluor technology (19). An additional sequence was added to one of the primers, known as the Z-sequence (5'-ACTGAACCTGACCGTACA-3'), which is complementary to the universal $\mathrm{Z}$ probe (Intergen Inc., Oxford, 
A

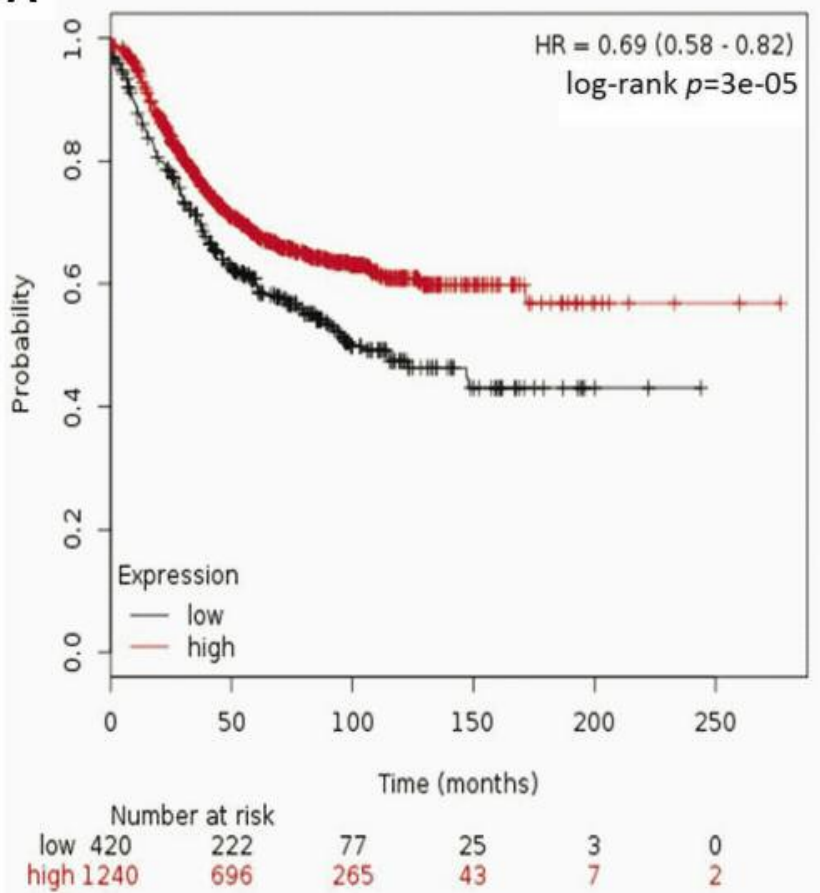

B

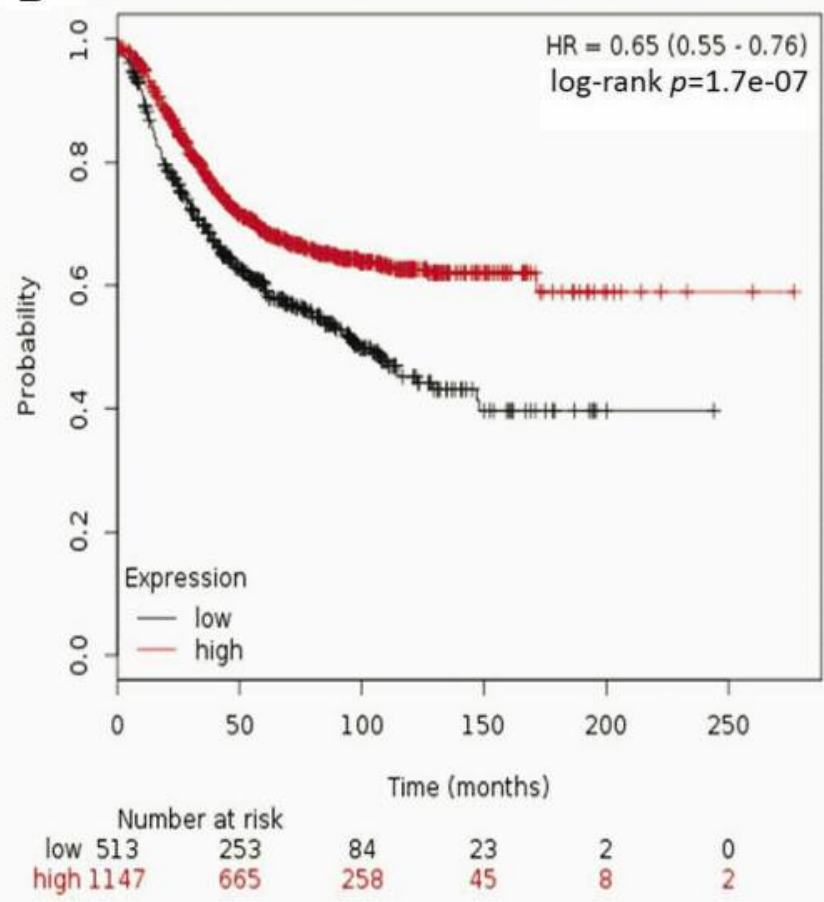

Figure 1. A high level of activin receptor-like kinase 7 (ALK7) expression in breast tumours correlates with longer overall survival. Kaplan-Meier model of survival according to ALK 7 expression in patients with breast cancer. Data were taken from Affymetrix microarrays only. A and B represent two different clinical datasets for breast cancer.

UK). The reaction was carried out on an iCycler-IQ ${ }^{\mathrm{TM}}$ (Bio-Rad, Hemel Hemstead, UK). The reactions were carried out at $95^{\circ} \mathrm{C}$ for $10 \mathrm{~min}, 100$ cycles of $95^{\circ} \mathrm{C}$ for $15 \mathrm{~s}, 55^{\circ} \mathrm{C}$ for $35 \mathrm{~s}$ and $72^{\circ} \mathrm{C}$ for 10 s. The primers used for qPCR included: ALK7 F: 5'GACATGAAAACATCCTTGGT-3', ALK7 R: 5'-ACTGAACCT GACCGTACATTCAGATACCAGCCAAAGTT-3'; GAPDH F: 5'CTGAGTACGTCGTGGAGTC-3', GAPDH R: 5'-ACTGAACC TGACCGTACACAGAGATGACCCTTTTG-3'.

Construction of ALK7 expression plasmid and the establishment of corresponding stable transfectants. ALK7 cDNA was generated by RT-PCR using the primers: 5'-ATGACCCGGGCGCTCTG-3' and 5'-TTAGGCTTTGCAGTCTTCTTTGACA-3'. Full-length wildtype $A L K 7$ was then cloned into a pEF6/V5-HisTOPO vector (Invitrogen, Paisley, Scotland, UK). Plasmids were sequenced and verified. pEF6-ALK7 and empty plasmids (pEF6-Empty) were transfected into both MDA-MB-231 and MCF-7 cells using an Easyjet Plus electroporator (EquiBio, Kent, UK). After 2 weeks of selection with $5 \mu \mathrm{g} / \mathrm{ml}$ blasticidin, the verified transfectants were clonally expanded and cultured in maintenance medium containing $2.5 \mu \mathrm{g} / \mathrm{ml}$ blasticidin. ALK7 overexpression was then confirmed by qPCR and western blot. The resulting cell lines were then named MCF-7 ALK7 OE1 and -2, and MDA-MB-231 ALK7 OE (OE overexpression). Control cell lines with integrated pEF6 empty vector were called MCF-7 or MDA-MB-231 pEF6.

In vitro cell growth assay. Cells $\left(3 \times 10^{3}\right.$ cells/well) were plated into 96-well plates and allowed to grow. Cells were fixed in $4 \%$ formalin after $24,72,120$ and $168 \mathrm{~h}$ of culture. The cells were then stained with $0.5 \%(\mathrm{w} / \mathrm{v})$ crystal violet solution. Following washing, stained crystal violet was dissolved with $10 \%(\mathrm{v} / \mathrm{v})$ acetic acid (20). Absorbance was then determined at $540 \mathrm{~nm}$ using an ELx800 spectrophotometer (BioTek).

In vitro cell-matrix adhesion. Cells $\left(2 \times 10^{4}\right)$ were added to each well of a 96-well plate, which was pre-coated with Matrigel (BD Biosciences, Oxford, UK). After 40 min of incubation, non-adherent cells were washed off using balanced salt solution buffer. The remaining cells were fixed with formalin and stained with crystal violet. The number of adherent cells was then counted under a microscope.

In vitro invasion assay. This was performed as previously reported and modified in our laboratory (21). Briefly, transwell inserts (Greiner Bio-One Ltd, Stonehouse, UK) with $8 \mu \mathrm{m}$ pores were coated with Matrigel and air-dried. The Matrigel was rehydrated for $40 \mathrm{~min}$ before use. Then $2 \times 10^{4}$ cells were seeded into each insert. After 72-h incubation, cells that had migrated through the matrix and adhered on the other side of the insert were fixed and stained with crystal violet. The number of invading cells were then counted under a microscope.

Western blot analysis. Equal amounts of protein $(20 \mu \mathrm{g})$ from breast cancer cell lysates, were separated using sodium dodecyl sulfate polyacrylamide gel electrophoresis and electroblotted into nitrocellulose membranes, and then blocked in 5\% milk in TBS- 
Tween20 $(0.5 \%)$. Proteins were then probed with the respective primary antibodies (GAPDH and ALK7 antibodies were obtained from Santa Cruz Biotechnology, Inc., Dallas, TX, USA) and corresponding peroxidase-conjugated secondary antibodies (Agilent Technologies Inc, Santa Clara, CA, USA). Protein bands were visualised using a chemiluminescence detection kit (Luminata; Millipore, Billerica, MA, USA) and visualised using a UVITech imager (UVITech, Cleaver Scientific Ltd, Rugby, UK). Bands were measured quantitatively using the Image $\mathbf{J}$ software.

Drug treatments and 3-(4,5-dimethylthiazol-2-yl)-2,5-diphenyltetrazolium bromide (MTT) cell viability assays. For the cytotoxicity experiments, we used tamoxifen, paclitaxel (Sigma, USA) and cisplatin (EDQM, France). Cells were seeded at $3 \times 10^{3}$ per well in 96-well plates for $24 \mathrm{~h}$. Cells were then treated with tamoxifen (0$100 \mu \mathrm{M})$, paclitaxel $(0-10 \mathrm{nM})$ or cisplatin $(0-300 \mu \mathrm{M})$ for 4 days. MTT solution $(0.5 \mathrm{mg} / \mathrm{ml})$ was then added to each well and incubation was continued for $4 \mathrm{~h}$ at $37^{\circ} \mathrm{C}$. Dimethyl sulfoxide was then added to dissolve the dye and the absorbance was then recorded at $540 \mathrm{~nm}$.

Statistical analysis. Statistical analysis was performed using SPSS 18 (SPSS Inc., Chicago, IL, USA). Mann-Whitney $U$-test was used for non-normally distributed data, and the $t$-test was used for normally distributed data. Survival was analysed using KaplanMeier survival analysis. Values of $p<0.05$ were considered statistically significant.

\section{Results}

High expression of ALK7 correlates with better survival in patients with breast cancer. We analyzed the clinical data of patients with breast cancer from Kmplot.com website - a manually curated database. Gene-expression data and relapse-free and overall survival information were downloaded into a database handled by a PostgreSQL server, which integrates gene expression and clinical data simultaneously. The Kaplan-Meier survival model was used to analyze the overall survival. We found high ALK7 expression was associated with longer overall survival of patients with breast cancer which can be seen from the two data sets $[\mathrm{n}=1660$. hazard ratio $(\mathrm{HR})=0.69, p<0.0001$; $\mathrm{n}=1660 . \mathrm{HR}=0.65, p<0.0001)$ (Figure 1).

Expression of ALK7 in breast cancer and breast cancer cell lines. The expression of $A L K 7$ was examined in breast cancer cell lines and a cohort of breast cancer tissues by qPCR analysis. From the clinical cohort, we found that the transcript levels were increased overall breast cancer samples compared with normal tissue. ALK7 expression decreased with increasing clinic stage of breast cancer (invasive ductal cancer patients with TNM stage 2, 3 or 4 expressed lower levels of ALK7 compared to those with TNM 1 stage, $p=0.014)$. In addition, patients with a higher Nottingham Prognostic Index had lower $A L K 7$ expression. However, these data did not reach significance. Furthermore, the relationship between expression of $A L K 7$ and ER was also analysed. There was a reduction in
ALK7 expression with $\mathrm{ER} \alpha$ and $\mathrm{ER} \beta$ positivity but again not reaching statistical significance.

We analyzed $A L K 7$ expression levels in eight human breast cancer cell lines. We found a high degree of variability across the cell line panel with BT-20. BT-549, BT483 and SK-BR-3 cell lines showing high expression, MCF-7 and MDA-MB-436 showing moderate expression, and MDAMB-231, ZR-75-1 showing low expression (Figure 2A).

As ALK7 expression levels were reduced in high-grade and high-stage breast cancer, we decided to further our studies using the MCF-7 and MDA-MB-231 cells as these two cell lines represent hormone-sensitive $\left(E R \alpha^{+}\right)$and triplenegative breast cancer cell lines, respectively, two of the most common breast cancer subtypes. Upon western blot for ALK7 protein, a reduced level of expression was seen in MDA-MB-231 compared to MCF-7 cells (Figure 2B and C).

Overexpression of ALK7 in breast cancer cell lines. In order to study the effects of ALK7 upon these breast cancer cells, we generated two stable breast cancer cell lines, MDA-MB-231 and MCF-7, ectopically expressing ALK7 cDNA. The overexpression of $A L K 7$ was verified in the stable cell lines using qPCR, and western blot (Figure 3). Increased expression of $A L K 7$ was seen in both $A L K 7$-overexpressing MDA-MB-231 ALK7 OE ALK7 OE and MCF-7 ALK7 OE cells compared to their corresponding controls including cells stably transfected with the empty plasmid and the wild-type parental cells.

ALK7 overexpression reduces growth, adhesion and invasion of breast cancer cells. The effects on cell functions induced by $A L K 7$ overexpression were examined by several assays, including cell growth, adhesion, and invasion. We firstly determined the effect of ALK7 overexpression on cell growth in vitro. Overexpression of $A L K 7$ in MCF-7 ALK7 OE cells significantly reduced the growth rate over 7 days (Figure 4A). MDA-MB-231 ALK7 OE cells showed a similar trend, but there was no significant difference compared to parental cell line.

Overexpression of $A L K 7$ in both MCF-7 and MDA-MB-231 cells had a significant influence on cell matrix adhesion. As shown in Figure 4B, overexpression of $A L K 7$ in MCF-7 ALK7 OE and MDA-MB-231 ALK7 OE cells significantly reduced cell adhesion (MCF-7 ALK7 OE1 $p=0.0319$; MCF-7 ALK7 OE $p=0.0318$; MDA-MB-231 ALK7 OE $p=0.0325$ ) compared with control wild-type cells.

Matrigel invasion assays were used to evaluate the invasive capability of breast cancer cells. Overexpression of ALK7 in MCF-7 ${ }^{\triangle \mathrm{ALK} 7}$ and MDA-MB-231 ${ }^{\triangle \mathrm{ALK} 7}$ cells reduced their invasive capability but not significantly $(p>0.05)$ (Figure $4 C)$.

ALK7 is repressed by Oestrogen in MCF-7 cells. We treated hormonally starved wild-type MCF-7 cells (72 h) with different concentrations of oestradiol and tamoxifen for 


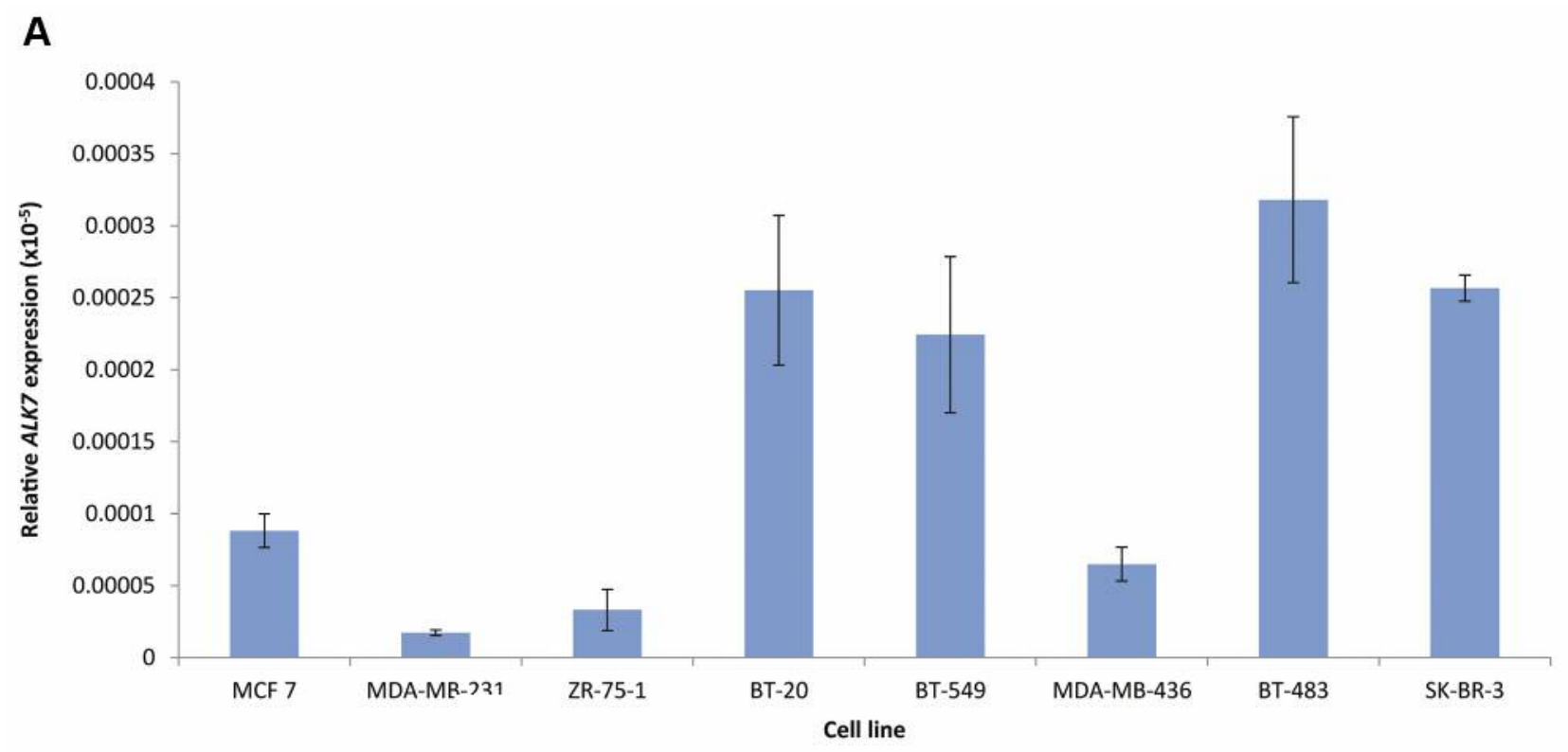

B

C
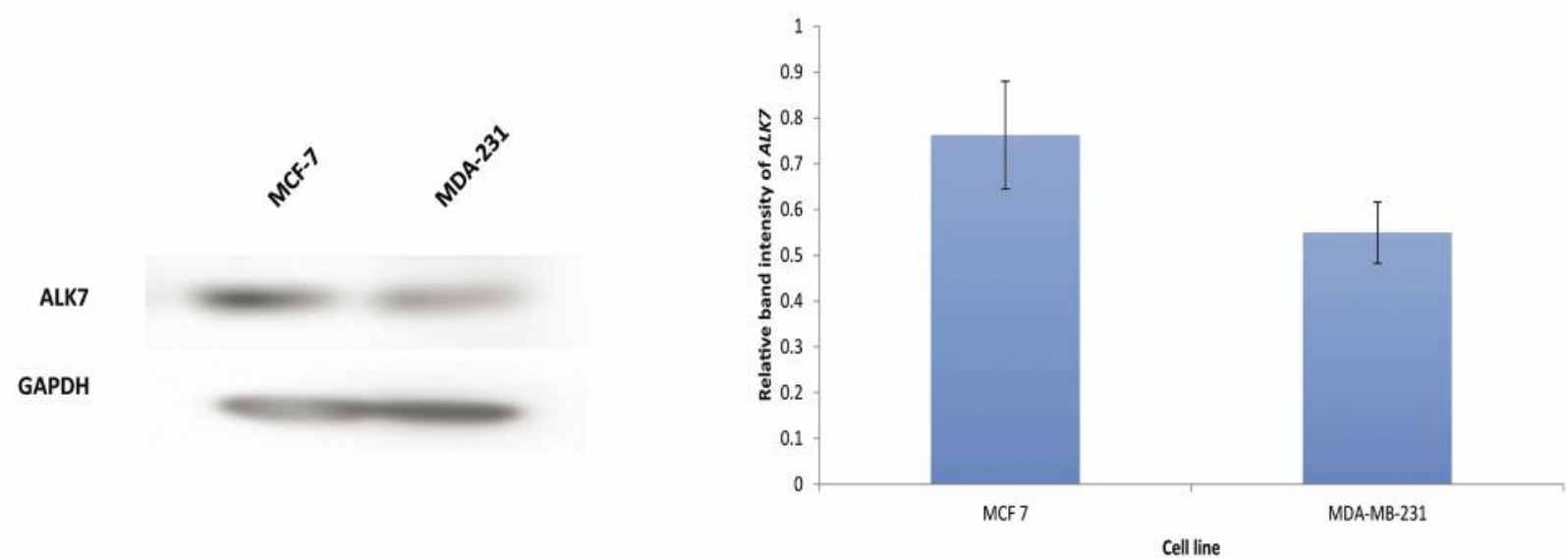

Figure 2. Expression of activin receptor-like kinase 7 (ALK7) in breast cancer cell lines. A: Analysis of ALK7 expression in a panel of breast cancer cells lines. Results represent the means $\pm S D$ of three independent experiments. Data were normalised to expression of glyceraldehyde-3-phosphate dehydrogenase (GAPDH) and $\beta$-actin. B: Western blot analysis of ALK7 protein expression in MCF-7 and MDA-MB-231 cell lines. Protein loading is shown by GAPDH. C: Densitometric analysis of western blot band intensity of ALK7, as normalised to GAPDH level.

$24 \mathrm{~h}$. Upon starvation of oestrogen, we saw a significant increase in $A L K 7$ expression, which was then reduced upon Oestrogen treatment (0.01-100 nM) (Figure $5 \mathrm{~A})$. As a positive control for Oestrogen activity in these cells, we monitored the increased expression of the oestrogen-regulated gene progesterone receptor $(P R)$ (Figure 5B). Tamoxifen treatment of wild-type MCF-7 cells in full medium (with oestrogen) led to a modest increase in expression at low doses (Figure 5C) thus verifying that ALK7 expression is in some way suppressed by Oestrogen. PR expression was significantly supressed by tamoxifen at all concentrations (Figure 5D).
Cytotoxicity of paclitaxel and cisplatin. In order to investigate the effects of $A L K 7$ on the chemotherapeutic responsiveness of breast cancer cell lines, we treated MCF7, MDA-MB-231, MCF-7 ALK7 OE and MDA-MB-231 ALK7 OE, with different concentrations of paclitaxel and cisplatin for $96 \mathrm{~h}$, followed by MTT cell viability assays. We found that overexpression of $A L K 7$ increased the sensitivity of MCF-7 cells to paclitaxel (Figure 6A), but had a smaller non-significant effect on MDA-MB-231 sensitivity (Figure 6B). However, ALK7 overexpression slightly increased resistance to cisplatin in both cell lines (Figure 7). 
A

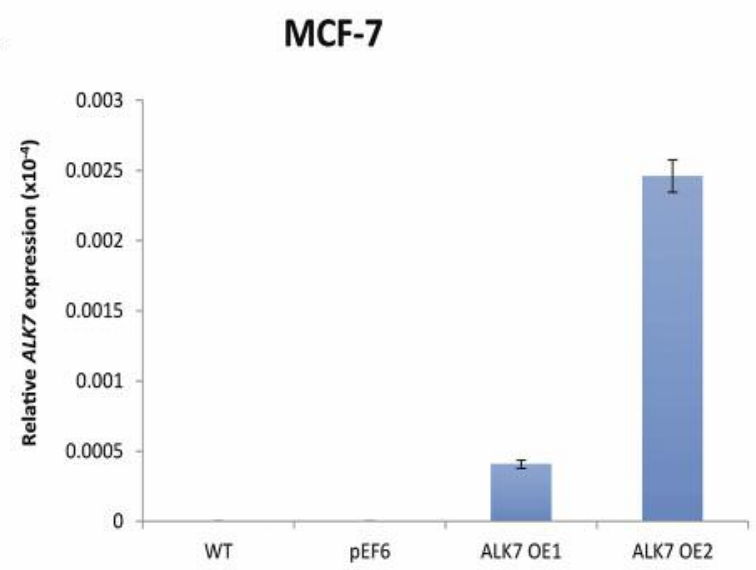

B

GAPDH

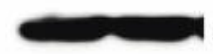

ALK7

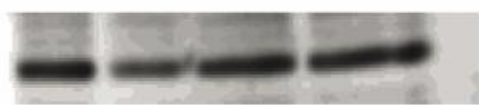

C

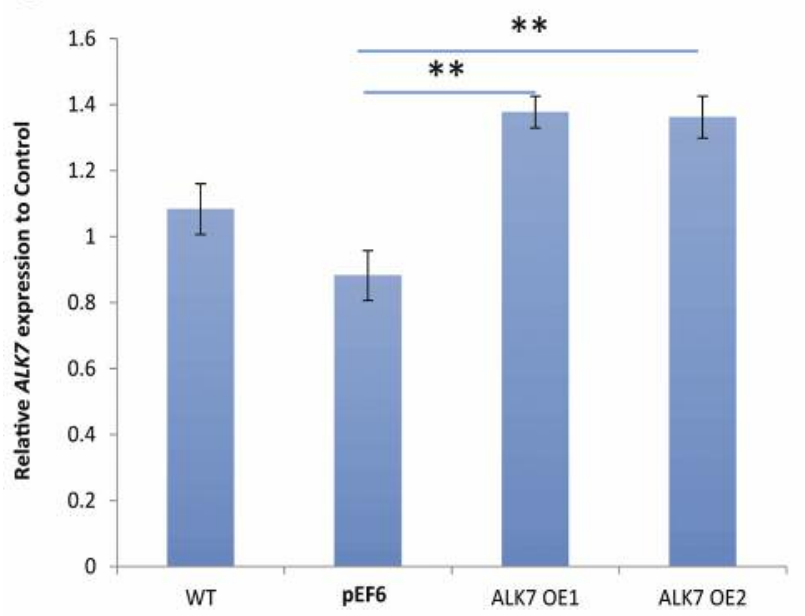

MDA-MB-231

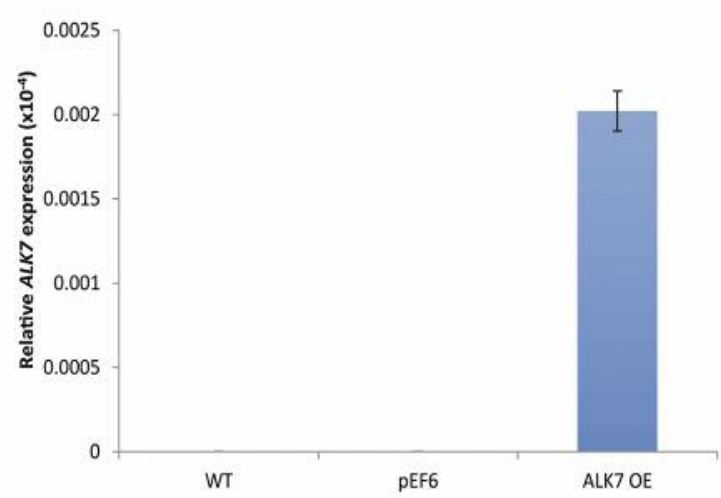

GAPDH

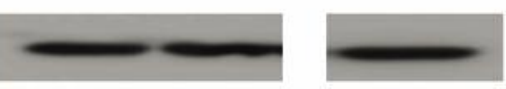

ALK7
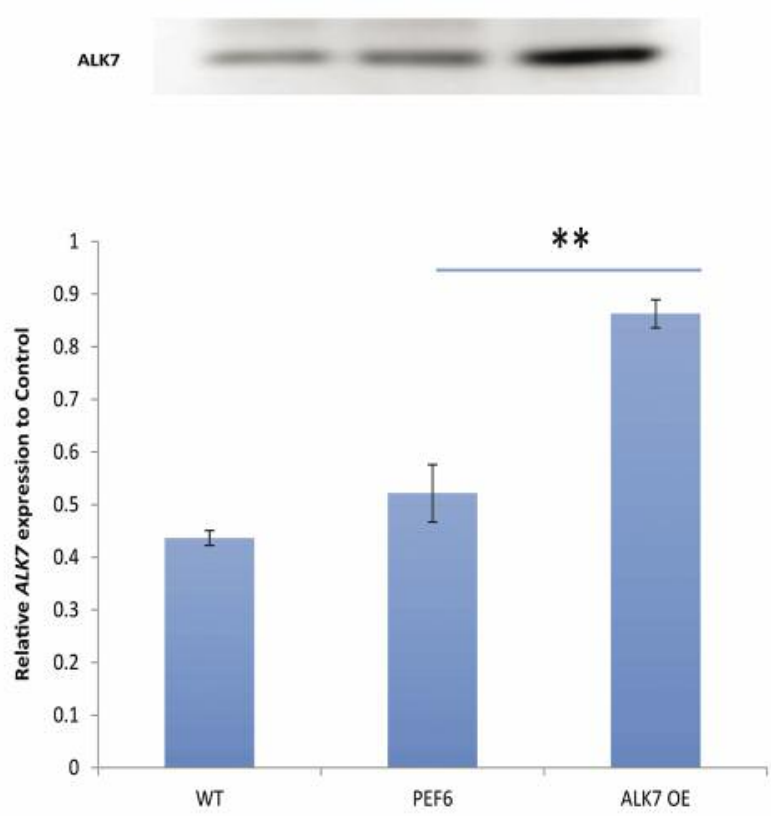

Figure 3. Overexpression of activin receptor-like kinase 7 (ALK7) in breast cancer cells. A: Analysis of ALK7 expression in MCF-7 (left hand side) and MDA-MB-231 (right hand side) ALK7-overexpressing (OE) cells compared to wild type (WT) and pEF6-empty control ( $p E F 6)$. B: Western blot analysis of ALK7 levels in MCF-7 (left hand side) and MDA-MB-231 (right hand side) overexpression cells in comparison to wild type and pEF6empty controls. Protein loading was verified by the glyceraldehyde-3-phosphate dehydrogenase (GAPDH) blot. C: Densitometric analysis of the western blot bands to determine the ratio of ALK7 expression in MCF-7 and MDA-MB-231 cells. **p<0.01, ***p<0.001, ****p<0.0001.

\section{Discussion}

The TGF- $\beta$ superfamily includes many structurally and functionally related growth factors (22). These factors initiate their cellular effects by binding to cell surface receptors, including type I and type II serine/threonine receptors. ALK7 is one such type I receptor. The loss or reduction of TGF- $\beta$ type II and type I receptor expression is a frequent genetic event in a variety of human cancer types (23-25). The activin type I receptor mRNA levels are significantly lower in prostate tumors when compared to non-malignant tissues (26). An early study reported immunohistochemical analyses showing 
A

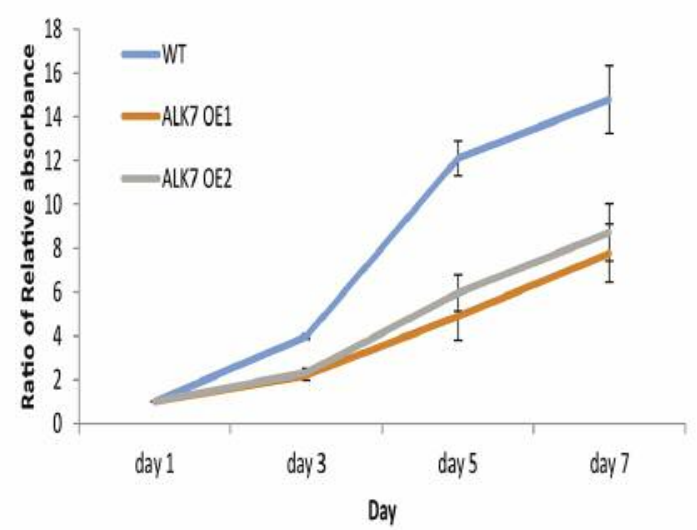

B
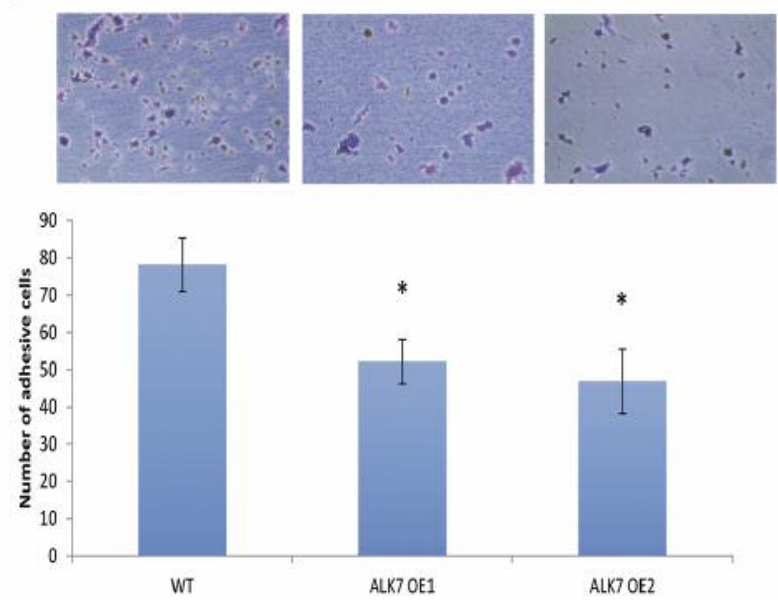

C
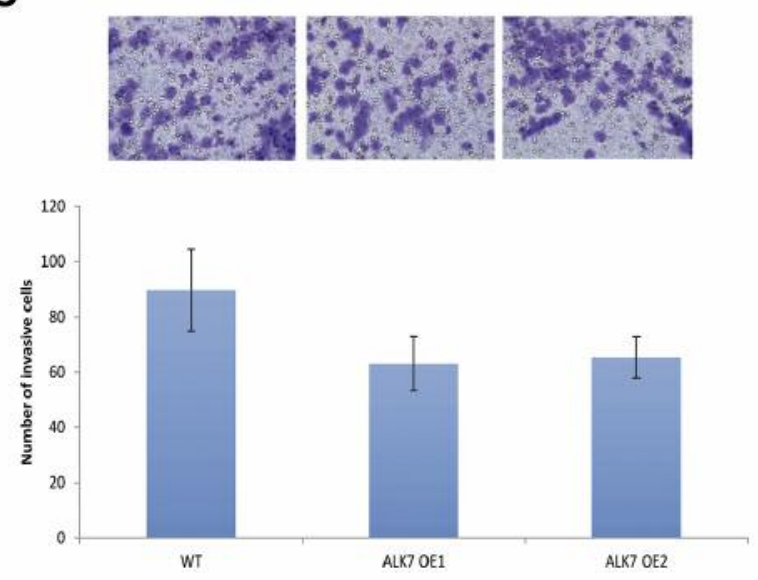

MDA-MB-231
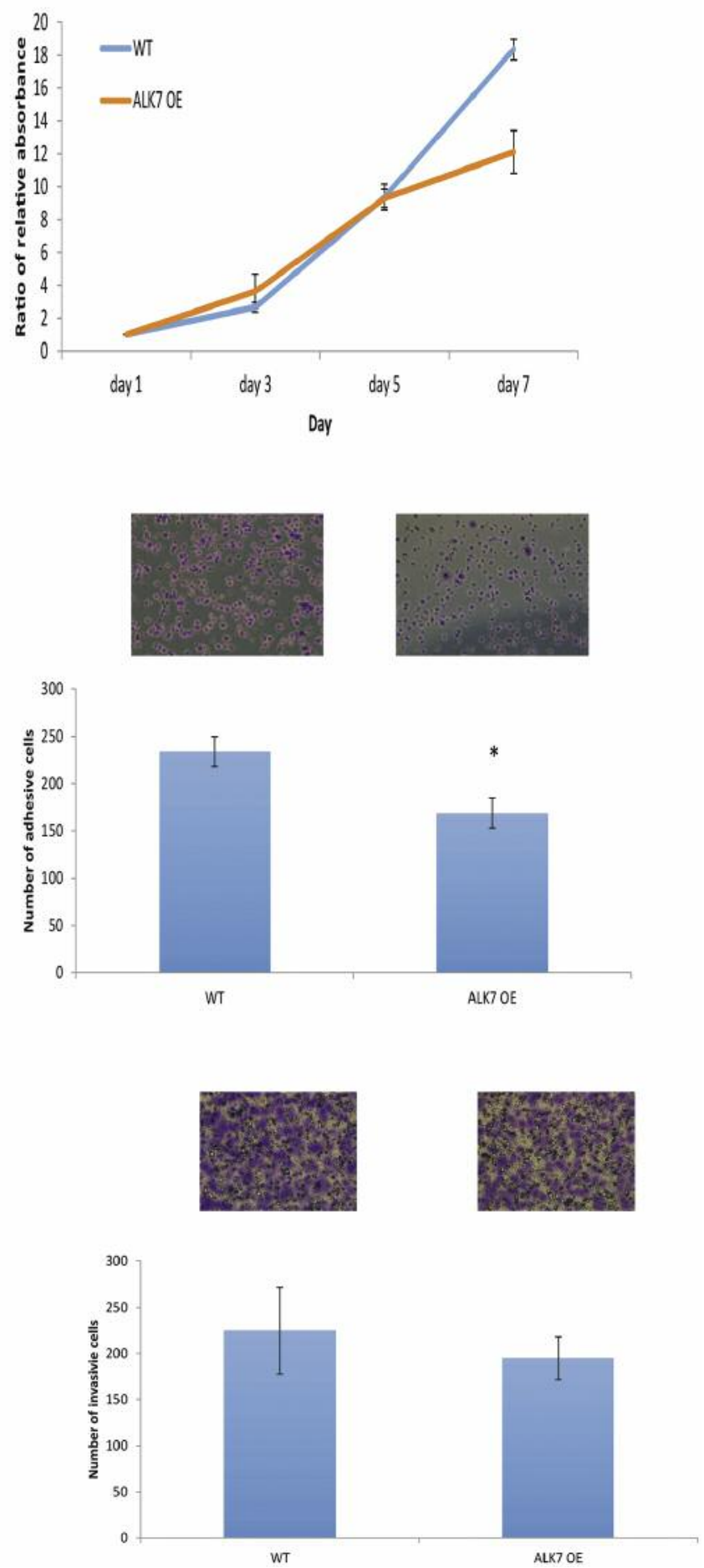

Figure 4. The effects of activin receptor-like kinase 7 (ALK7) overexpression on cell growth, adhesion, and invasion by breast cancer cells. A: Cell proliferation assays of MCF-7 ALK7-overexpressing (OE) and MDA-MB-231 ALK7 OE cells compared with wild-type (WT) controls over 7 days. Data were normalised to day 1. B: Cell adhesion assays of MCF-7 ALK7 OE and MDA-MB-231 ALK7 OE cells compared to wild-type controls. Data represent mean cell counts from three independent experiments. C: Invasion assays of MCF-7 ALK7 OE and MDA-MB-231 ALK7 OE cells compared with wild-type controls. Data represents mean cell counts from three independent experiments. Cells were stained with crystal violet and representative images are shown. $* p<0.05, * * p<0.01$. 
A

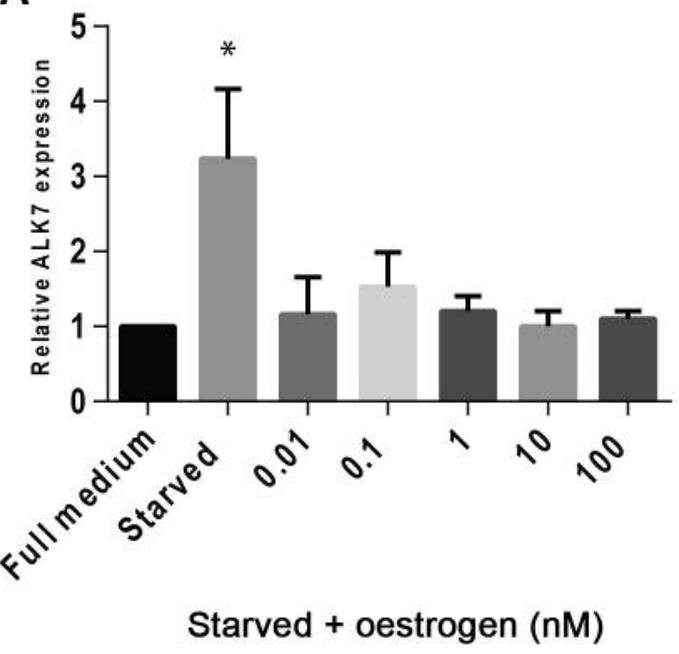

C

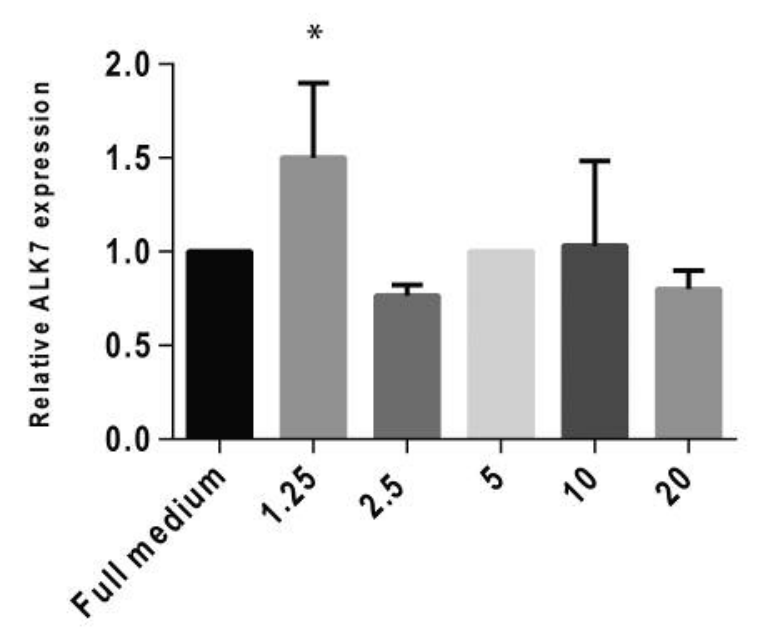

Tamoxifen $(\mu M)$
B

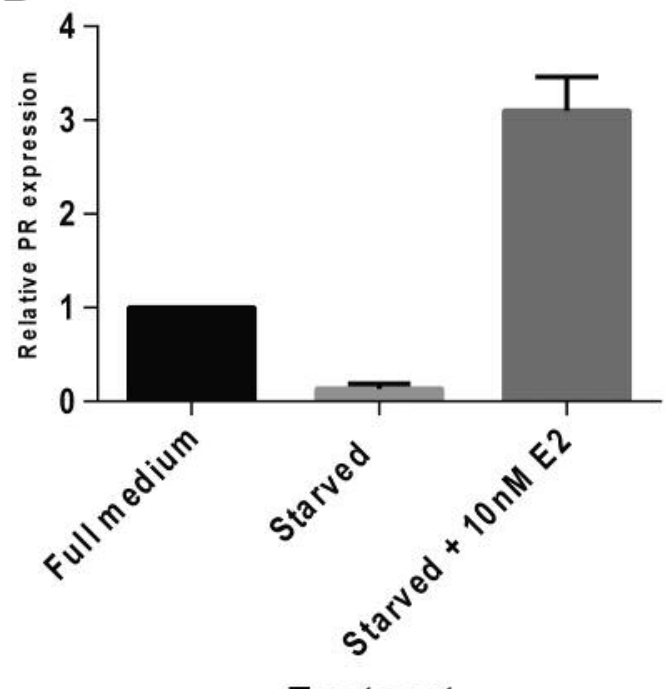

Treatment

D

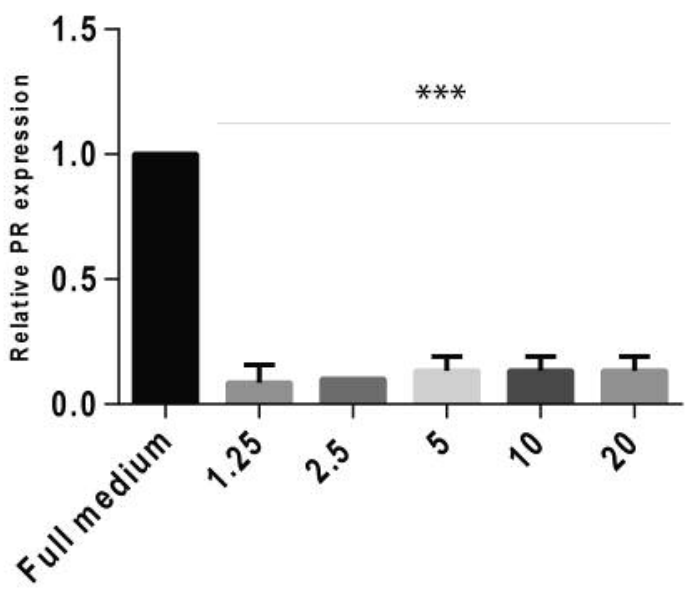

Tamoxifen $(\mu \mathrm{M})$

Figure 5. Activin receptor-like kinase 7 (ALK7) expression is Oestrogen regulated in MCF-7 cells. A: Quantitative polymerase chain reaction (Q$P C R)$ analysis of ALK7 expression levels in MCF-7 cells grown hormonally starved for $72 \mathrm{~h}$, and then treated with increasing doses of oestrogen (0-100 nM). B: Q-PCR analysis of progesterone receptor (PR) expression levels in MCF-7 cells grown hormonally starved for $72 \mathrm{~h}$, and then treated with $10 \mathrm{nM}$ Oestrogen (E2). C: Q-PCR analysis of ALK7 expression levels in MCF-7 cells grown in full medium treated with increasing doses of tamoxifen $(0-20 \mu \mathrm{M})$ for $24 \mathrm{~h}$. D: Q-PCR analysis of progesterone receptor (PR) expression levels in MCF-7 cells grown in full medium treated with increasing doses of tamoxifen $(0-20 \mathrm{mM})$ for $24 \mathrm{~h} . * p<0.05, * * p<0.01, * * * p<0.001$.

that ALK7 was more frequently and much more intensely expressed in adjacent normal tissues, adenosis, and fibroadenoma tissues than in malignant tissues (ductal carcinoma in situ, invasive ductal cancer, and lymph node metastasis). Patients with pancreatic ductal adenocarcinoma with a lack of ALK7 expression survived for a significantly shorter time than patients with positive ALK7 expression (17).
Lack of ALK7 expression was confirmed as a factor of poor prognosis in patients with PDAC by others (27). According to the Kaplan-Meier survival model from the Kmplot database, we found that patients with breast cancer with high ALK7 expression had longer overall survival. These findings suggest that the abnormal expression of TGF- $\beta$ superfamily receptors may be important for the progression of cancer. 
A
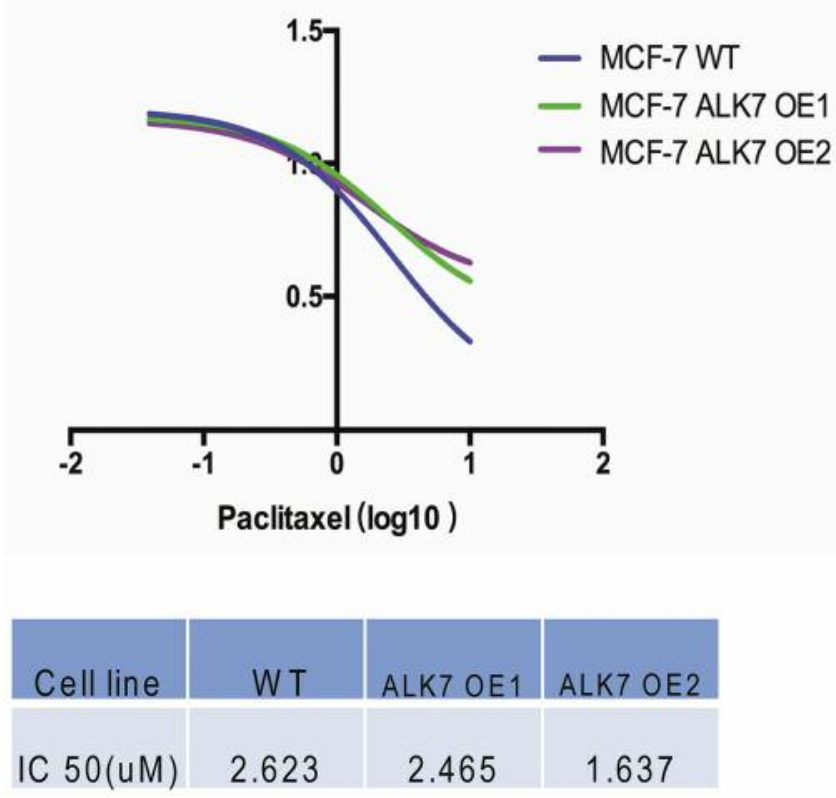

B

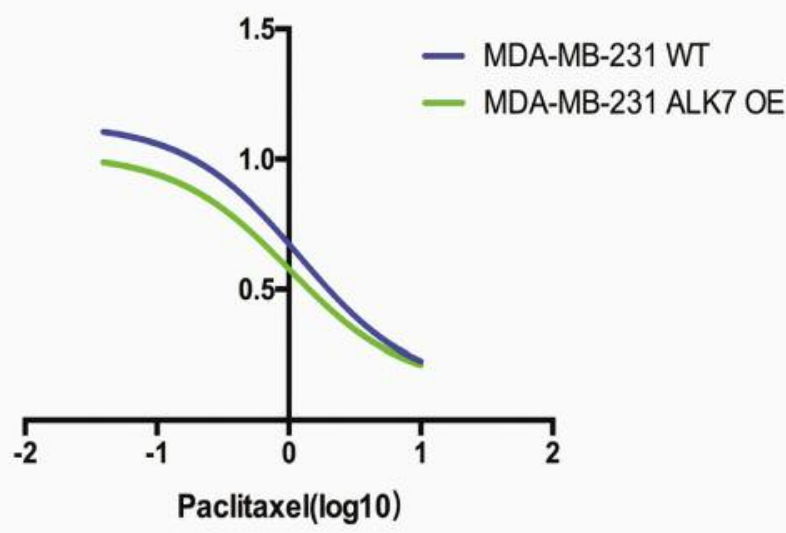

Figure 6. Cytotoxicity assays of MCF-7 activin receptor-like kinase 7 (ALK7)-overexpressing (OE) and MDA-MB-231 ALK7 OE cells compared to their parental cell lines. Cell proliferation assays of MCF-7 (A) and MDA-MB-231 (B) cells treated with increasing concentrations of paclitaxel $(\mu M)$ for 96 h. The half-maximal inhibitorory concentration $\left(I C_{50}\right)$ for paclitaxel for each cell line is given below each graph.

A

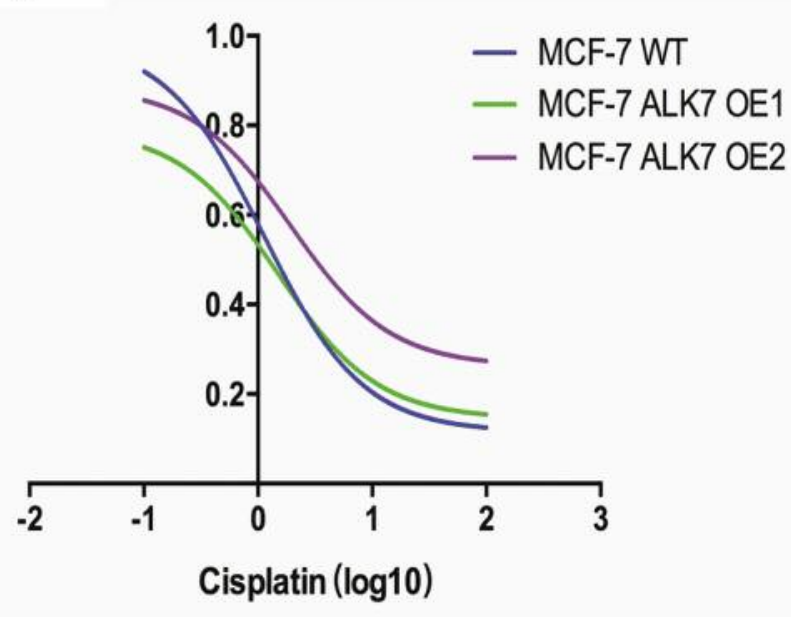

B

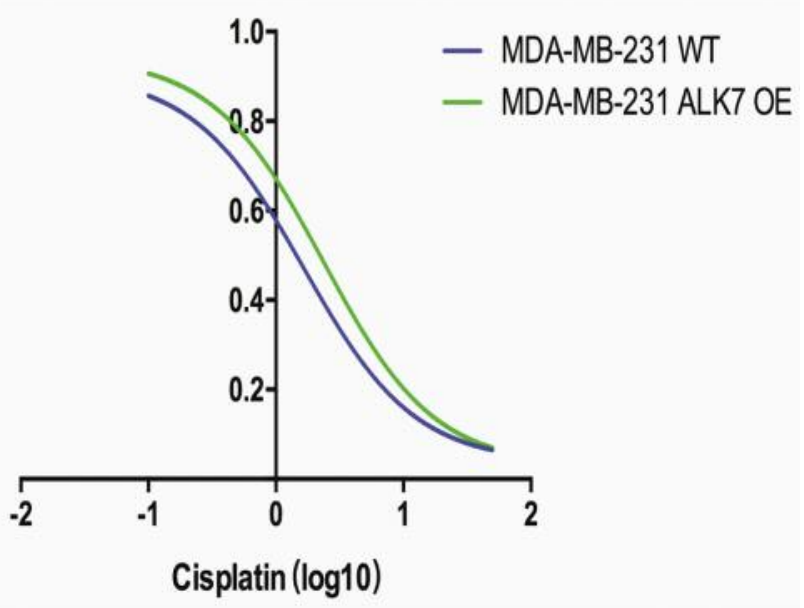

Figure 7. Cytotoxicity assays of MCF-7 activin receptor-like kinase (ALK7)-overexpressing (OE) and MDA-MB-231 ALK7 OE cells compared to their parental cell lines. Cell proliferation assays were carried out of MCF-7 (A) and MDA-MB-231 (B) cells treated with increasing concentrations of cisplatin $(\mu M)$ for $96 \mathrm{~h}$. The half-maximal inhibitorory concentration $\left(I C_{50}\right)$ for cisplatin for each cell line is given below each graph. 
ALK7 influences cell proliferation and induces cell apoptosis and these effects have been found in a rat neuronal cell line, hepatoma cells, human trophoblast cells and ovarian cancer cells $(12,14-16,19)$. We also found a similar phenomenon in breast cancer cell lines MDA-MB-231 and MCF-7 and this was consistent with the result from a study on ZR-75-30 breast cancer cell (17). Activins are ligands of ALK7. Activin has complex effects on cell growth during branching morphogenesis, but it is generally considered as an inhibitor of cell proliferation (28). Activin B inhibits cell proliferation in many cell types $(29,30)$. Therefore, presumably, activin B inhibits the proliferation of breast cancer cells. Activin B-treated ZR-75-30 breast cancer cells showed decreased cell proliferation after overexpressing ALK7 (22).

Nodal signals through type II activin receptors, including ALK7 (9, 31). Activation of ALK7 was shown to inhibit cell proliferation and to induce morphological differentiation in the rat neuronal cell line PC12 (11) ALK7 also induced apoptosis in a variety of cell types, such as hepatoma, trophoblast, epithelial ovarian cancer cells $(12,15,16)$. Nodal has similar growth-inhibiting, apoptosis-inducing effects to ALK7 on trophoblast and ovarian cancer cells (14). Previous studies have shown that nodal, acting through ALK7 and SMAD2/3, exerts antiproliferative and apoptotic effects on human trophoblast and ovarian cancer cells $(15,16,32)$. In breast cancer cells, nodal and ALK7 up-regulated the cell-cycle inhibitors p27 and p21 (18). Nodal and ALK7 have been reported to inhibit AKT activity, as well as the expression of X-linked inhibitor of apoptotic protein (XIAP) (22). It has also has been reported that nodal and ALK7 reduced expression of B-cell lymphoma 2 (BCL2) and B-cell lymphoma-extra large $\left(\mathrm{BCL}-\mathrm{X}_{\mathrm{L}}\right)$, and caspase-3 was activated significantly. Therefore, overexpression of ALK7 may reduce cell growth through the nodal/ALK7 pathway. But involvement of these pathways in the negative regulation of ALK7 on growth, adhesion and invasion of breast cancer cell is yet to be investigated. From the results of treatment with oestrogen we saw that ALK7 expression was repressed by oestrogen in MCF-7 cells, and found increased expression when oestrogen was removed or inhibited by the oestrogen antagonist tamoxifen. We also saw reduced ALK7 expression in the clinical cohort in $\mathrm{ER} \alpha^{+}$and $\mathrm{ER} \beta^{+}$samples (albeit not significantly). We found that ALK7 overexpression increased the sensitivity of MCF-7 cells to paclitaxel but slightly reduced the sensitivity of breast cancer cells to cisplatin. The mechanism of how ALK7 overexpression influences the sensitivity of MCF-7 cells to chemotherapies is still unknown. One hypothesis is via the influence of ALK7 on AKT activity and XIAP expression $(13,16,33)$, which has been reported to promote chemoresistance in ovarian cancer cells (34-37).

We found ALK7 expression to be inversely correlated with survival and disease stage and grade. Overexpression of ALK7 results in reduced cell growth and invasive/motility characteristics of breast cancer cells. Interestingly, ALK7 seems to be repressed by Oestrogen in ER ${ }^{+}$MCF-7 cells, which have a modest ALK7 expression compared to $\mathrm{ER}^{-}$ MDA-MB-231 cells which showed high expression. Given that ALK7 expression can alter sensitivity to commonly used chemotherapeutic agents paclitaxel and cisplatin, the fact that oestrogens and ER-modulatory therapies (e.g. tamoxifen) commonly used in $\mathrm{ER}^{+}$breast cancer may affect ALK7 expression levels and subsequent response to chemotherapy should be taken into account.

\section{Acknowledgements}

The Authors would like to thank The Cardiff University-Peking University Cancer Institute for funding this work.

\section{References}

1 Derynck $\mathrm{R}$ and Zhang YE: SMAD-dependent and smadindependent pathways in TGF-beta family signalling. Nature 425(6958): 577-584, 2003.

2 Attisano L and Wrana JL: Signal transduction by the TGF-beta superfamily. Science 296(5573): 1646-1647, 2002.

3 Graham H and Peng C: Activin receptor-like kinases: Structure, function and clinical implications. Endocr Metab Immune Disord Drug Targets 6(1): 45-58, 2006.

4 Massague J: Tgfbeta in cancer. Cell 134(2): 215-230, 2008.

5 Abe Y, Minegishi T and Leung PC: Activin receptor signaling. Growth Factors 22(2): 105-110, 2004.

6 Chang CF, Westbrook R, Ma J and Cao D: Transforming growth factor-beta signaling in breast cancer. Front Biosci 12: 43934401, 2007.

7 Miyazawa K, Shinozaki M, Hara T, Furuya T and Miyazono K: Two major smad pathways in tgf-beta superfamily signalling. Genes Cells 7(12): 1191-1204, 2002.

8 Ryden M, Imamura T, Jornvall H, Belluardo N, Neveu I, Trupp $\mathrm{M}$, Okadome T, ten Dijke P and Ibanez CF: A novel type i receptor serine-threonine kinase predominantly expressed in the adult central nervous system. J Biol Chem 271(48): 3060330609, 1996.

9 Reissmann E, Jornvall H, Blokzijl A, Andersson O, Chang C, Minchiotti G, Persico MG, Ibanez CF and Brivanlou AH: The orphan receptor ALK7 and the activin receptor ALK4 mediate signaling by nodal proteins during vertebrate development. Genes Dev 15(15): 2010-2022, 2001.

10 Tsuchida K, Nakatani M, Yamakawa N, Hashimoto O, Hasegawa $\mathrm{Y}$ and Sugino H: Activin isoforms signal through type I receptor serine/threonine kinase ALK7. Mol Cell Endocrinol 220(1-2): 59-65, 2004.

11 Jornvall H, Blokzijl A, ten Dijke P and Ibanez CF: The orphan receptor serine/threonine kinase ALK7 signals arrest of proliferation and morphological differentiation in a neuronal cell line. J Biol Chem 276(7): 5140-5146, 2001.

12 Kim BC, van Gelder H, Kim TA, Lee HJ, Baik KG, Chun HH, Lee DA, Choi KS and Kim SJ: Activin receptor-like kinase-7 induces apoptosis through activation of MAPKs in a SMAD3dependent mechanism in hepatoma cells. J Biol Chem 279(27): 28458-28465, 2004. 
13 Zhang N, Kumar M, Xu G, Ju W, Yoon T, Xu E, Huang X Gaisano H, Peng C and Wang Q: Activin receptor-like kinase 7 induces apoptosis of pancreatic beta cells and beta cell lines. Diabetologia 49(3): 506-518, 2006.

14 Munir S, Xu G, Wu Y, Yang B, Lala PK and Peng C: Nodal and ALK7 inhibit proliferation and induce apoptosis in human trophoblast cells. J Biol Chem 279(30): 31277-31286, 2004

15 Xu G, Zhong Y, Munir S, Yang BB, Tsang BK and Peng C: Nodal induces apoptosis and inhibits proliferation in human epithelial ovarian cancer cells via activin receptor-like kinase 7 . J Clin Endocrinol Metab 89(11): 5523-5534, 2004.

$16 \mathrm{Xu} \mathrm{G}$, Zhou H, Wang Q, Auersperg N and Peng C: Activin receptor-like kinase 7 induces apoptosis through up-regulation of $B A X$ and down-regulation of XIAP in normal and malignant ovarian epithelial cell lines. Mol Cancer Res 4(4): 235-246, 2006.

17 Zeng F, Xu G, Zhou T, Yang C, Wang X, Peng C and Zhou H: Reduced expression of activin receptor-like kinase 7 in breast cancer is associated with tumor progression. Med Oncol 29(4): 2519-2526, 2012.

18 Zhong Y, Xu G, Ye G, Lee D, Modica-Amore J and Peng C: Nodal and activin receptor-like kinase 7 induce apoptosis in human breast cancer cell lines: Role of caspase 3. Int J Physiol Pathophysiol Pharmacol 1(1): 83-96, 2009.

19 Jiang WG, Watkins G, Fodstad O, Douglas-Jones A, Mokbel K and Mansel RE: Differential expression of the CCN family members CYR61, CTGF and NOV in human breast cancer. Endocr Relat Cancer 11(4): 781-791, 2004.

20 Jiang WG, Davies G, Martin TA, Parr C, Watkins G, Mason MD, Mokbel $\mathrm{K}$ and Mansel RE: Targeting matrilysin and its impact on tumor growth in vivo: The potential implications in breast cancer therapy. Clin Cancer Res 11(16): 6012-6019, 2005.

21 Jiang WG, Hiscox S, Hallett MB, Horrobin DF, Mansel RE and Puntis MC: Regulation of the expression of E-cadherin on human cancer cells by gamma-linolenic acid (gla). Cancer Res 55(21): 5043-5048, 1995.

22 Zeng F: Expression, function and clinical significance of nodal and its receptor ALK7 and ALK4 in breast cancer. Doctoral Dissertation, University of Electronic Science and Technology of China, 2014.

23 Levy L and Hill CS: Alterations in components of the tgf-beta superfamily signaling pathways in human cancer. Cytokine Growth Factor Rev 17(1-2): 41-58, 2006.

24 Kim IY, Ahn HJ, Lang S, Oefelein MG, Oyasu R, Kozlowski JM and Lee C: Loss of expression of transforming growth factorbeta receptors is associated with poor prognosis in prostate cancer patients. Clin Cancer Res 4(7): 1625-1630, 1998.

25 Lazzereschi D, Ranieri A, Mincione G, Taccogna S, Nardi F and Colletta G: Human malignant thyroid tumors displayed reduced levels of transforming growth factor beta receptor type ii messenger RNA and protein. Cancer Res 57(10): 2071-2076, 1997.

26 van Schaik RH, Wierikx CD, Timmerman MA, Oomen MH, van Weerden WM, van der Kwast TH, van Steenbrugge GJ and de Jong FH: Variations in activin receptor, inhibin/activin subunit and follistatin mRNAs in human prostate tumour tissues. Br J Cancer 82(1): 112-117, 2000.
27 Liu C, Yang Z, Li D, Liu Z, Miao X, Yang L, Zou Q and Yuan $\mathrm{Y}$ : Overexpression of $\mathrm{B} 2 \mathrm{M}$ and loss of ALK7 expression are associated with invasion, metastasis, and poor-prognosis of the pancreatic ductal adenocarcinoma. Cancer Biomark 15(6): 735$743,2015$.

28 Reis FM, Luisi S, Carneiro MM, Cobellis L, Federico M, Camargos AF and Petraglia F: Activin, inhibin and the human breast. Mol Cell Endocrinol 225(1-2): 77-82, 2004.

29 Mather JP, Roberts PE and Krummen LA: Follistatin modulates activin activity in a cell- and tissue-specific manner. Endocrinology 132(6): 2732-2734, 1993.

30 Phillips DJ, Brauman JN, Mason AJ, de Kretser DM and Hedger MP: A sensitive and specific in vitro bioassay for activin using a mouse plasmacytoma cell line, MPC-11. J Endocrinol 162(1): 111-116, 1999.

31 Sakuma R, Ohnishi Yi Y, Meno C, Fujii H, Juan H, Takeuchi J, Ogura T, Li E, Miyazono K and Hamada H: Inhibition of nodal signalling by lefty mediated through interaction with common receptors and efficient diffusion. Genes Cells 7(4): 401-412, 2002.

32 Xu G, Bernaudo S, Fu G, Lee DY, Yang BB and Peng C: Cyclin G2 is degraded through the ubiquitin-proteasome pathway and mediates the antiproliferative effect of activin receptor-like kinase 7. Mol Biol Cell 19(11): 4968-4979, 2008.

33 Wang H, Jiang JY, Zhu C, Peng C and Tsang BK: Role and regulation of nodal/activin receptor-like kinase 7 signaling pathway in the control of ovarian follicular atresia. Mol Endocrinol 20(10): 2469-2482, 2006.

34 Asselin E, Mills GB and Tsang BK: XIAP regulates AKT activity and caspase-3-dependent cleavage during cisplatininduced apoptosis in human ovarian epithelial cancer cells. Cancer Res 61(5): 1862-1868, 2001.

35 Fraser M, Bai $\mathrm{T}$ and Tsang BK: AKT promotes cisplatin resistance in human ovarian cancer cells through inhibition of p53 phosphorylation and nuclear function. Int J Cancer 122(3): 534-546, 2008.

36 Sasaki H, Sheng Y, Kotsuji F and Tsang BK: Down-regulation of X-linked inhibitor of apoptosis protein induces apoptosis in chemoresistant human ovarian cancer cells. Cancer Res 60(20): 5659-5666, 2000.

37 Yang X, Fraser M, Moll UM, Basak A and Tsang BK: AKTmediated cisplatin resistance in ovarian cancer: Modulation of p53 action on caspase-dependent mitochondrial death pathway. Cancer Res 66(6): 3126-3136, 2006.
Received May 4, 2017

Revised May 24, 2017

Accepted May 30, 2017 